\title{
The influence of the number of students in practice groups about the practice beliefs, knowledge, and ability.
}

\author{
Julian Kraja ${ }^{1}$, Zamira Shabani ${ }^{2}$
}

Received: 05 October 2021 / Accepted: 26 October 2021 / Published online: 20 January 2022

This article is published with open access at $\boldsymbol{h t t p s : / / j o u r n a l . a s t e s . o r g . a l}$

(C) The author(s) 2022. \& Copyright (C) 2022, the Albanian Society for Trauma and Emergency Surgery

(c) The Albanian Journal of Trauma and Emergency Surgery is an Open Access Journal. All articles are distributed under the terms of the Creative Commons Attribution Non-Commercial License: http://creativecommons.org/licenses/by-nc/4.0/) which permits unrestricted non-commercial use, distribution, and reproduction in any medium provided the original work is properly cited.

\begin{abstract}
Background: Professional practice in the nursing study program was conducted with groups of 10 to 12 students and we have had an excellent experience until 2018. While during the academic year 2019-2020 we were forced to form internship groups of 20 students, which has brought major problems in their progress and management.

Methods: The study was conducted with nursing students in second and third year of study, in bachelor's degree in "General Nursing".

Results: There were major changes in reported knowledge of professional practice. There are substantial differences between years of study and between groups of 10 and 20 students in practice.

Conclusions: Special attention should be paid to professional practice when designing teaching curricula. It should occupy about $35 \%$ of the total curriculum and the practice groups should be as small as possible.
\end{abstract}

Key words: bachelor nursing program, nursing students, practice groups, professional practices.

\section{Introduction}

Professional practices are one of the most important areas that help in understanding the importance of nursing student performance in the clinical territory and its impact on the development of the nursing profession [1].

Integrating professional values into students in nursing education is essential to guarantee the future of nursing. [2].

Clinical placements where students learn professional practice should allow students to acquire nursing skills and clinical reasoning and develop as professional nurses, because nursing education is a combination of theoretical and practical learning experiences [3].

The professional practice experience is an important

Original article, no submission or publication in advance or in parallel

* Corresponding author:

Julian Kraja

* julian.kraja@unishk.edu.al

1. Nursing Department - University of Shkodra "Luigj Gurakuqi", ALBANIA aspect of learning nursing practices that enables students to relate theoretical and conceptual knowledge [4]. Professional practices are an important part of the nursing curriculum, in which students apply the knowledge acquired at university [5].

The Bachelor of Nursing Study program aims to develop nursing students who are competent to provide safe and effective services to society, especially on the part of of professional practice, therefore, the nursing curriculum needs to be aligned with the environment where professional practices will take place to ensure that graduates are equipped to meet the challenges of a complex and dynamic healthcare delivery system [6].

The nursing diploma includes $32.5 \%$ of the credits envisaged for the formation of students in clinical settings [5].

The nursing bachelor study program at the University of Shkodra "Luigj Gurakuqi" provides $32.2 \%$ of the total credits for professional practices. Whereas according to decision no. 41, dated January 24, 2018 "On the elements of study programs offered by Higher Education Institutions", Annex No. 1, Table No.1, Professional Practice cannot be more than 15\%, including language foreign and informational knowledge [7]. 
Professional practice in the nursing study program were conducted with groups of 10 to 12 students and we had an excellent experience until 2018. While during the academic year 2019-2020 we were forced to form internship groups of 20 students, which has brought major problems in their progress and management. This phenomenon occurred because as health centers as well as small units in hospitals are unable to cope with such a large number of students. This change is according to decision no. 41, dated 24 January 2018 "On the elements of study programs offered by Higher Education Institutions", Annex no.1, table no.2, teaching groups, the number of students in professional practice should be 20 students (VKM 2018). One of the modern means of learning, which can be used to introduce the desired skills, is the problem-based learning, which takes constructivist learning theory as its basis [8].

For evidence-based practice to take place in patient management or clinical education, it is necessary to know the principles of evidence-based practice needed, including how to retrieve, appraise, and apply evidence, and is the conscientious and judicious use of current best evidence in conjunction with clinical expertise and patient values to guide health care decisions [9]. Evidence-based practice are innovative interventions that are based on best practices, one such technique is quickly gaining popularity due to its potential to effectively handle clinical issues and provide better patient care [10]. Attitudes and beliefs are important concepts in understanding, classroom practices, change, and learning to teach, therefore, are important considerations in understanding classroom practices and in-service teachers develop their thinking and practices [11].

This practice is essential for nursing profession as well as it offers a wide variety of benefits: It helps nurses to develop their body of knowledge, minimize the gap between training, research, and practice in nursing, standardize nursing practices, and practice, standardize nursing practices, thus, clinical decision-making by nurses should be based on the best and most up-to-date, available research evidence [12].

The purpose of this study was to examine the evidencebased practice beliefs and knowledge of nursing students and to determine whether differences in self-reported beliefs or knowledge existed based upon respondent characteristics of year of study and number of students present in practice.

\section{Material and methods}

Our study, is transverse method, or cross-sectional method as it is otherwise known, was used, following a quantitative approach. The following components were evaluated during the study: Perceptions about the importance of professional practice, self-assessment of knowledge gained from professional practice and the difference brought about by the change from small groups to large groups in the realization and benefit of professional practice.

We recruited to participate in this study were students in second and third year of study at Nursing Department in University of Shkodra. In this study participated 50 students at the second academic year, but during the first academic year have realized the professional practice in groups with 10-12 members. Also, in this study participated 50 students of the third academic year of nursing study program that actually are in groups with 20 members in the practice and in the two past academic years they have realized the practice in small groups with 10-12 members. This study was realized during June 2019 after they have finished the professional practice of academic year respectively.

Data collection was made using the Clinical Effectiveness and Evidence Based Practice Questionnaire, was designed to measure evidence-based practice knowledge, beliefs, and use (D Upton \& P Upton, 2005) ${ }^{13}$. Also adjusted to look at changes in benefit from changing the number of students in groups. The tool was used to collect information on the evidence-based beliefs and practical knowledge of respondents.

Data were analyzed using the Statistical Package for the Social Sciences (SPSS) version 19 (IBM Corp. in Armonk, NY). Respondents rated their level of agreement with belief statements on a five-point scale with the following response options: strongly disagree, disagree, neither agree nor disagree, agree, or strongly agree. Knowledge level was ranked on a five-point scale, rather than the original seven-point scale, with the following choices: poor, fair, good, very good, or excellent. As the intent of this study was to examine respondents 'attitudes and knowledge of students in clinical practice. Likert scale responses were assigned numerical values to allow for statistical analysis (Likert-type scale). The second part of the questions refers to students' perceptions of how they evaluated their performance and professional practices from small groups to large groups. Also, for the 100 students interviewed, other socio-demographic data were requested such as gender, age (correspondence to years of study), relevant year of study.

Permission to do this work was obtained from the Department of Nursing at the University of Shkodra. This record respects the rules of data protection. The study was seen as a professional practice improvement activity and not as research involving human subjects. They could then decide whether, or not to participate. Questionnaire responses were strictly anonymous to ensure students' privacy.

\section{Results}

A total of 100 students completed surveys. The majority of respondents were females $(87 \%, \mathrm{n}=87)$ and $50 \%$ were in the second year of study and 50\% were in third year.in this sample $13 \%$ were 19 years old, $36 \%$ were 20 years old, $42 \%$ were 21 years old, $6 \%$ were 22 years old, $1 \%$ were 23 years old and $2 \%$ of them 24 years old. STDEV $= \pm 0.98$ year and mean 20.5 years old, minimum 19 years old and maximum 24 years old. 
Table. 1. Self-reported Evidence-based Practice Beliefs and Knowledge

\begin{tabular}{|l|c|c|c|c|c|}
\hline Evidence-based Practice Statement & $\begin{array}{l}\text { Strongly } \\
\text { Disagree }\end{array}$ & Disagree & $\begin{array}{l}\text { Neither Agree } \\
\text { or Disagree }\end{array}$ & Agree & $\begin{array}{l}\text { Strongly } \\
\text { Agree }\end{array}$ \\
\hline New evidence is important I make time & 0 & 1 & 7 & 23 & 69 \\
\hline Evidence-based practice is fundamental to practice & 2 & 0 & 5 & 11 & 82 \\
\hline My practice has changed because of evidence & 6 & 6 & 21 & 32 & 35 \\
\hline My workload is too great for me to keep up to date & 38 & 27 & 17 & 6 & 12 \\
\hline Evidence based practice is a waste of time & 90 & 4 & 4 & 1 & 1 \\
\hline I stick to tried and trusted methods & 14 & 11 & 25 & 27 & 23 \\
\hline $\begin{array}{l}\text { Formulated a clearly answerable question as the } \\
\text { beginning of the process towards filling this gap }\end{array}$ & 1 & 3 & 13 & 18 & 65 \\
\hline $\begin{array}{l}\text { Tracked down the relevant evidence once } \\
\text { you have formulated the question: }\end{array}$ & 1 & 1 & 34 & 37 & 27 \\
\hline $\begin{array}{l}\text { Critically appraised, against set criteria, } \\
\text { any literature you have discovered: }\end{array}$ & 1 & 4 & 18 & 31 & 46 \\
\hline $\begin{array}{l}\text { Integrated the evidence you have found } \\
\text { with your expertise: }\end{array}$ & 0 & 7 & 20 & 33 & 40 \\
\hline Evaluated the outcomes of your practice: & 2 & 1 & 19 & 33 & 45 \\
\hline Shared this information with colleagues: & 3 & 11 & 26 & 15 & 45 \\
\hline
\end{tabular}

Table. 2. Self-reported Evidence-based Practice Ability

\begin{tabular}{|c|c|c|c|c|c|c|c|c|c|c|}
\hline \multirow[t]{2}{*}{$\begin{array}{l}\text { Evidence-based Practice } \\
\text { Component }\end{array}$} & \multicolumn{2}{|c|}{$\begin{array}{l}\text { Strongly } \\
\text { Disagree }\end{array}$} & \multicolumn{2}{|c|}{ Disagree } & \multicolumn{2}{|c|}{$\begin{array}{l}\text { Neither Agree } \\
\text { or Disagree }\end{array}$} & \multicolumn{2}{|c|}{ Agree } & \multicolumn{2}{|c|}{$\begin{array}{l}\text { Strongly } \\
\text { Agree }\end{array}$} \\
\hline & Gr.10 & Gr.20 & Gr.10 & Gr.20 & Gr.10 & Gr.20 & Gr.10 & Gr.20 & Gr.10 & Gr.20 \\
\hline Research skills & 1 & 37 & 0 & 38 & 6 & 17 & 16 & 4 & 77 & 4 \\
\hline IT skills & 12 & 35 & 7 & 26 & 17 & 17 & 29 & 9 & 35 & 13 \\
\hline $\begin{array}{l}\text { Monitoring and reviewing of } \\
\text { practice skills }\end{array}$ & 2 & 36 & 3 & 23 & 6 & 29 & 23 & 9 & 66 & 3 \\
\hline $\begin{array}{l}\text { Converting your information } \\
\text { needs into a research question }\end{array}$ & 5 & 35 & 3 & 21 & 17 & 19 & 35 & 14 & 40 & 11 \\
\hline $\begin{array}{l}\text { Ability to identify gaps in your } \\
\text { professional practice }\end{array}$ & 3 & 35 & 2 & 26 & 5 & 21 & 26 & 8 & 64 & 10 \\
\hline $\begin{array}{l}\text { Knowledge of how to retrieve } \\
\text { evidence }\end{array}$ & 2 & 24 & 5 & 25 & 9 & 26 & 34 & 13 & 50 & 12 \\
\hline $\begin{array}{l}\text { Ability to analyse critically } \\
\text { evidence against set standards }\end{array}$ & 2 & 33 & 3 & 30 & 14 & 21 & 38 & 10 & 43 & 6 \\
\hline $\begin{array}{l}\text { Ability to determine how valid } \\
\text { the material is }\end{array}$ & 4 & 27 & 3 & 27 & 16 & 18 & 28 & 15 & 49 & 13 \\
\hline $\begin{array}{l}\text { Ability to determine how useful } \\
\text { the material is }\end{array}$ & 4 & 24 & 4 & 27 & 11 & 21 & 31 & 14 & 50 & 14 \\
\hline $\begin{array}{l}\text { Ability to apply information to } \\
\text { individual cases }\end{array}$ & 3 & 36 & 1 & 28 & 5 & 19 & 31 & 9 & 60 & 8 \\
\hline $\begin{array}{l}\text { Sharing of ideas and } \\
\text { information with colleagues }\end{array}$ & 2 & 23 & 6 & 23 & 11 & 23 & 26 & 12 & 55 & 19 \\
\hline $\begin{array}{l}\text { Dissemination of new ideas } \\
\text { about care to colleagues }\end{array}$ & 2 & 25 & 6 & 22 & 9 & 22 & 22 & 8 & 61 & 23 \\
\hline $\begin{array}{l}\text { Ability to review your own } \\
\text { practice }\end{array}$ & 2 & 31 & 4 & 27 & 6 & 17 & 22 & 13 & 66 & 12 \\
\hline
\end{tabular}

group of 10 students / group of 20 students 
Perception about the importance of professional practice, professional self-assessment of knowledge used by professional practices by students and the difference brought about by the change from small groups to large groups in the realization and benefit of professional practice.

Many respondents reported positive beliefs about evidence-based practice (Table 1 and Table 2). Respondents most often selected agree or strongly agree for the following positive belief statements: welcome questions on practice $(69 \%, \mathrm{n}=69)$; evidence-based practice is fundamental to practice $(82 \%, \mathrm{n}=82)$; and my practice changed because of evidence $(67 \%, n=67)$. For the following negative belief statements, respondents most often selected the disagree or strongly disagree response option: evidence-based practice is a waste of time (94\%, $\mathrm{n}=94)$; and I stick to tried and trusted methods $(25 \%$, $\mathrm{n}=25)$. The responses about the belief statement that workload is too great to keep up to date were split: $18 \%$ $(n=18)$ agree or strongly agree; $65 \%(n=65)$ disagree or strongly disagree; and $17 \%(\mathrm{n}=17)$ neutral. The highest percentage of respondents accept that new evidence is important: agree or strongly agree $92 \%(n=92)$.

There was a difference between highest degree groups of studies and level of agreement with two of the belief statements: new evidence is important $(\mathrm{R}=0.12)$, evidencebased practice is a waste of time $(\mathrm{R}=-0.08)$, evidence-based practice is fundamental to practice $(\mathrm{R}=-0.09)$, shared this information with colleagues $(\mathrm{R}=-0.07)$, (Table 3$)$. There was no difference between highest degree groups and other belief statements or age and any of the statements.

Table. 3. Correlation between Evidence-based Practice Statement and year of study

\begin{tabular}{|l|l|}
\hline Evidence-based Practice Statement & R-Pearson \\
\hline New evidence is important I make time & 0.12 \\
\hline Evidence-based practice is fundamental to practice & -0.09 \\
\hline My practice has changed because of evidence & 0.14 \\
\hline My workload is too great for me to keep up to date & 0.08 \\
\hline Evidence based practice is a waste of time & -0.08 \\
\hline I stick to tried and trusted methods & 0.09 \\
\hline Formulated a clearly answerable question as the beginning of the process towards filling this gap: & 0.21 \\
\hline Tracked down the relevant evidence once you have formulated the question: & 0.14 \\
\hline Critically appraised, against set criteria, any literature you have discovered: & 0.05 \\
\hline Integrated the evidence you have found with your expertise: & 0.07 \\
\hline Evaluated the outcomes of your practice: & 0.07 \\
\hline Shared this information with colleagues: & -0.07 \\
\hline Pearson correlation coefficient & \\
\hline
\end{tabular}

Table. 4. Differences in Evidence-based Practice Ability between groups of students

\begin{tabular}{|l|c|c|}
\hline Evidence-based Practice Component & Gr.10 & Gr.20 \\
\hline Research skills & 0.82 & -0.94 \\
\hline IT skills & 0.92 & -0.92 \\
\hline Monitoring and reviewing of practice skills & 0.86 & -0.92 \\
\hline Converting your information needs into a research question & 0.95 & -0.94 \\
\hline Ability to identify gaps in your professional practice & 0.87 & -0.96 \\
\hline Knowledge of how to retrieve evidence & 0.94 & -0.83 \\
\hline Ability to analyse critically evidence against set standards & 0.95 & -0.98 \\
\hline Ability to determine how valid the material is & 0.95 & -0.95 \\
\hline Ability to determine how useful the material is & 0.94 & -0.89 \\
\hline Ability to apply information to individual cases & 0.89 & -0.98 \\
\hline Sharing of ideas and information with colleagues & 0.92 & -0.63 \\
\hline Dissemination of new ideas about care to colleagues & 0.88 & -0.42 \\
\hline Ability to review your own practice & 0.86 & -0.96 \\
\hline group of 10 students / group of 20 students & & \\
\hline
\end{tabular}


Table. 5. Differences in Evidence-based Practice ability between students according to the year

\begin{tabular}{|l|l|l|}
\hline Evidence-based Practice Component & $\mathbf{2}$ year & $\mathbf{3}$ year \\
\hline Research skills & 0.03 & -0.04 \\
\hline IT skills & 0.12 & 0.20 \\
\hline Monitoring and reviewing of practice skills & -0.07 & -0.05 \\
\hline Converting your information needs into a research question & -0.02 & 0.15 \\
\hline Ability to identify gaps in your professional practice & -0.09 & -0.05 \\
\hline Knowledge of how to retrieve evidence & 0.18 & 0.04 \\
\hline Ability to analyse critically evidence against set standards & 0.12 & -0.03 \\
\hline Ability to determine how valid the material is & -0.03 & 0.15 \\
\hline Ability to determine how useful the material is & -0.16 & 0.11 \\
\hline Ability to apply information to individual cases & -0.05 & -0.02 \\
\hline Sharing of ideas and information with colleagues & -0.08 & 0.13 \\
\hline Dissemination of new ideas about care to colleagues & -0.14 & 0.12 \\
\hline Ability to review your own practice & -0.11 & 0.20 \\
\hline Sophomores / third year students & & \\
\hline
\end{tabular}

Table 6. Mean score evaluation about practice beliefs and knowledge

\begin{tabular}{|l|l|}
\hline Evidence-based Practice Statement & R-Pearson \\
\hline Formulated a clearly answerable question as the beginning of the process towards filling this gap: & 4.43 \\
\hline Tracked down the relevant evidence once you have formulated the question: & 4.43 \\
\hline Critically appraised, against set criteria, any literature you have discovered: & 4.17 \\
\hline Integrated the evidence you have found with your expertise: & 4.03 \\
\hline Evaluated the outcomes of your practice: & 4.18 \\
\hline Shared this information with colleagues: & 3.88 \\
\hline New evidence is important I make time & 4.6 \\
\hline Evidence-based practice is fundamental to practice & 4.71 \\
\hline My practice has changed because of evidence & 3.84 \\
\hline My workload is too great for me to keep up to date & 2.27 \\
\hline Evidence based practice is a waste of time & 1.19 \\
\hline I stick to tried and trusted methods & 3.34 \\
\hline Pearson correlation coefficient & \\
\hline
\end{tabular}

Table. 7. Mean score evaluation about practice ability between groups of students

\begin{tabular}{|l|l|c|}
\hline Evidence-based Practice Component & Mean score gr10 & Mean score gr20 \\
\hline Research skills & 4.68 & 2 \\
\hline IT skills & 3.68 & 2.39 \\
\hline Monitoring and reviewing of practice skills & 4.48 & 2.2 \\
\hline Converting your information needs into a research question & 4.02 & 2.45 \\
\hline Ability to identify gaps in your professional practice & 4.46 & 2.32 \\
\hline Knowledge of how to retrieve evidence & 4.25 & 2.7 \\
\hline Ability to analyze critically evidence against set standards & 4.17 & 2.26 \\
\hline Ability to determine how valid the material is & 4.15 & 2.6 \\
\hline Ability to determine how useful the material is & 4.19 & 2.67 \\
\hline Ability to apply information to individual cases & 4.44 & 2.25 \\
\hline Sharing of ideas and information with colleagues & 4.26 & 2.84 \\
\hline Dissemination of new ideas about care to colleagues & 4.34 & 2.82 \\
\hline Ability to review your own practice & 4.46 & 2.47 \\
\hline Mean score group of 10 students / Mean score group of 20 students & & \\
\hline
\end{tabular}


In table 4 and table 5 we can see that are difference ability between groups of students in practice. In small groups is not possible to apply the ability and skills in practice. In all these components we can see that $\mathrm{R}$ Pearson are negative. That is evident also for each sample of degree of studies. The students of second and third year are coherent in the answers about the ability. Only for the IT skills and knowledge of how to retrieve evidence they admit that the number of members in the practice group doesn't influence. In all other ability and skills, they admit that increasing the number of students in practice group, decrease the possibility to apply, to identify gaps monitoring, sharing, review and to dissemination ideas and information in practice.

In the table 6 and table 7 we have evidence the mean score evaluation about practice beliefs and knowledge and mean score evaluation about practice ability between groups of students in most part of sample this score evaluation is over 3.75 point for practice beliefs and knowledge. The mean score evaluation about practice ability for practice group with 10 persons is 4.2 and for practice group with 20 persons is 2.4 point. This enforce our conviction that the number of students in practice should be reduced from 20 to 10 or less possible.

\section{Discussion}

The study showed that the number of students in the groups of professional internships is significant and has a convincing effect on the best realization of internship hours in the patient's bed. Student groups should have as few students as possible because professional practice will be more efficient, this is directly related to the report tutor and clinical instructor / student, as reported by Gemuhay et al [3]. The problem is that the institutions of higher education that offer bachelor study programs in nursing, cannot act in contradiction with the bylaws. According to Zwane et al, legislative institutions should communicate with stakeholders to avoid confusion and various problems [14]. Respondents often reported positive beliefs about evidence-based practice and the possession of evidencebased practical knowledge. However, some respondents reported negative beliefs such as disagreement over the importance of new evidence. There were wide variations in practical knowledge based on reported evidence. The largest percentage of respondents rated knowledge as good, average or "average" on the five-point scale. There were differences in evidence-based practice beliefs and knowledge between groups for number of students in practice and the year of study. the mean score evaluation about practice beliefs and knowledge and mean score evaluation about practice ability between groups of students. According to Jamshidi et al, poor evaluation of professional practices comes from a number of reasons ranging from inadequate preparation, insufficient time to develop professional practices, feelings of professional inferiority, lack of skills to deal with patients' problems, etc [15]. In most part of sample this score evaluation is over 3.75 point for practice beliefs and knowledge. The mean score evaluation about practice ability for practice group with 10 persons is 4.2 and for practice group with 20 person is 2.4 point. The clinical practice is not efficient in big number of students per group of practice because the possibility to apply the skills and ability reduce and the students cannot do their normal activities. This will influence in the performance of their profession. The number of students in practice should be reduced from 20 to 10 or less possible.

\section{Conclusion}

Professional practice should have the main weight in nursing curricula being oriented by those of the European Union.

All actors who contribute to the formation of the nurse, including higher education institutions and the Order of the Albanian Nurse, should meet and discuss about nursing curricula on an ongoing basis.

Organize congresses, conferences, or workshops from these institutions to discuss topics related to nursing curricula.

Universities offering bachelor's degree programs in Nursing should propose to the Ministry of Education, Youth and Sports of Albania, to change the decision about nursing curricula and to give priority to professional practice.

Our study focuses on two main aspects: on the evaluation of the importance of professional practice for students and the problems posed by the increase in the number of students in practice groups. The clinical practice is not efficient in large number of students per group of practice. The nursing bachelor study programs they are not the same as other study programs, because they must have a large percentage of professional practice and as such must be given the importance of hours and credits (ECTS). The practice groups should not be the same as other study programs, as professional practice take place near the patient bed, and we can't have a large number of students. Bachelor study programs in nursing should be designed according to the guidelines of the European Union, therefore these guidelines should be taken into account.

\section{Authorship Statement}

All authors meet the authorship criteria. Quantification of contribution: JK 50\%, ZS 50\%.

\section{Financial Disclosure}

The authors declare that they have no relevant financial interest.

This article has not been published in any journal before. 


\section{References}

1. Dadgaran I, Parvizy S, Peyrovi H. (2012). Nursing students' views of sociocultural factors in clinical learning: a qualitative content analysis. Japan Journal Nursing Science. 2013; 10 (1):1-9. doi: 10.1111/j.1742-7924. 00205.x. [PubMed: 23735085]

2. Poorchangizi, B., Borhani, F., Abbaszadeh, A. et al. (2019). The importance of professional values from nursing students' perspective. BMC Nurs 18, 26. https://doi.org/10.1186/ s12912-019-0351-1

3. Gemuhay HM, Kalolo A, Mirisho R, Chipwaza B, Nyangena E. (2019) «Factors Affecting Performance in Clinical Practice among Preservice Diploma Nursing Students in Northern Tanzania", Nursing Research and Practice, Article ID 3453085, 9 pages, 2019. https://doi.org/10.1155/2019/ 3453085

4. Karen F. Phillips, Mathew L, Aktan N, Catano B. (2017, April 10). Clinical education and student satisfaction: An integrative literature review. International Journal of Nursing Sciences, Volume 4, Issue 2, Pages 205-213 https://doi.org/10.1016/j. ijnss.2017.03.004 [Elsevier]

5. Lapeña-Moñux YR, Cibanal-Juan L, Orts-Cortés I, MaciáSoler L, Palacios-Ceña D. (2016). Nurses' experiences working with nursing students in a hospital: a phenomenological enquiry. Revista Latino-Americana de Enfermagem. 24: e2788 DOI: $10.1590 / 1518-8345.1242 .2788$

6. Bvumbwe, T. (2016, September 1). Enhancing nursing education via academic-clinical partnership: An integrative review. International Journal of Nursing Sciences. Chinese Nursing Association. https://doi.org/10.1016/j. ijnss.2016.07.002
7. VKM, nr. 41, 2018. http://qbz.gov.al/Botime/Akteindividuale/ Janar\%202018/Fletore\% 206/VKM\%20 nr. \% 241，\% 20 date\%2024.1.2018.pdf

8. Pjetri E, Kraja J, Dibra V, Belisha S, Curri Z. (2015). Nursing school documentation: knowledge, attitude, and barriers to using standardised nursing languages and current practices in nursing department and Shkodra Hospital. J Environ Prot Eco, 16, No 1, 292-297.

9. Titler MG. (2008, Apr). The Evidence for Evidence-Based Practice Implementation. In: Hughes RG, editor. Patient Safety and Quality: An Evidence-Based Handbook for Nurses. Rockville (MD): Agency for Healthcare Research and Quality (US); Chapter 7. PMID: 21328760.

10. Majid S, Foo S, Luyt B, Zhang X, Theng YL, Chang YK, Mokhtar IA. (2011. Jul). Adopting evidence-based practice in clinical decision making: nurses' perceptions, knowledge, and barriers. J Med Libr Assoc; 99(3):229-36. doi: 10.3163/15365050.99.3.010. PMID: 21753915; PMCID: PMC3133901.

11. Richardson V. 1996. The role of attitudes and beliefs in learning to teach. Handbook of Research on Teacher Education. Second Edition. Chapter: The Role of Attitudes and Beliefs in Learning to Teach.

12. Abu-Baker, N.N., AbuAlrub, S., Obeidat, R.F. et al. (2021). Evidence-based practice beliefs and implementations: a crosssectional study among undergraduate nursing students. BMC Nurs 20, 13. https://doi.org/10.1186/s12912-020-00522-x

13. Upton \& Upton P.M. (2005). EBPQ C D.R. https://ebpq. co.uk/ 